\title{
Community structure and productivity of subtidal turf and foliose algal assemblages
}

\author{
Robert J. Miller ${ }^{1, *}$, Daniel C. Reed ${ }^{1}$, Mark A. Brzezinski ${ }^{1,2}$ \\ ${ }^{1}$ Department of Ecology, Evolution, and Marine Biology, University of California, Santa Barbara, California 93106, USA \\ ${ }^{2}$ Marine Science Institute, University of California, Santa Barbara, California 93106, USA
}

\begin{abstract}
Foliose and turf-forming macroalgae form morphologically distinct assemblages on shallow reefs worldwide and frequently coexist in a patch mosaic. The relative contributions of these algal assemblages to reef productivity and the processes that maintain them, however, have rarely been studied. We found high $(80 \%)$ species overlap between turfs and foliose macroalgae at Naples Reef off southern California, with differences between the 2 assemblages lying in species dominance and morphology rather than composition. Turfs were dominated by a small finely-branched red alga, Pterosiphonia dendroidea, while larger blade-forming red algae, particularly Chondracanthus corymbiferus and Rhodymenia californica, dominated foliose assemblages. Foliose dominants were common in turfs, but were small. Areaspecific rates of net primary production of foliose assemblages were $\sim 3 \times$ higher than those of turfs, while rates of carbon-specific production and turnover times of turfs were $\sim 3 \times$ higher than those of foliose assemblages. These findings suggest that factors other than the growth potential of each assemblage determined their relative biomass. Turfs were net heterotrophic, with net community production $<0$, due to greater abundance of macrofauna, compared to foliose assemblages. The abundance of macrofaunal invertebrates was uncorrelated with productivity within or among assemblages, suggesting that turfs are structurally better habitats for macrofauna. Our results suggest that maintenance of turf assemblages on Naples Reef is not the result of competitive exclusion of foliose algae by turf species; turf morphology appears to be maintained through the stunting of foliose forms by fishes that crop turfs while foraging for invertebrate prey.
\end{abstract}

KEY WORDS: Primary production - California - Macrofauna $\cdot$ Net primary production $\cdot$ NPP $\cdot$ Turf algae

Resale or republication not permitted without written consent of the publisher

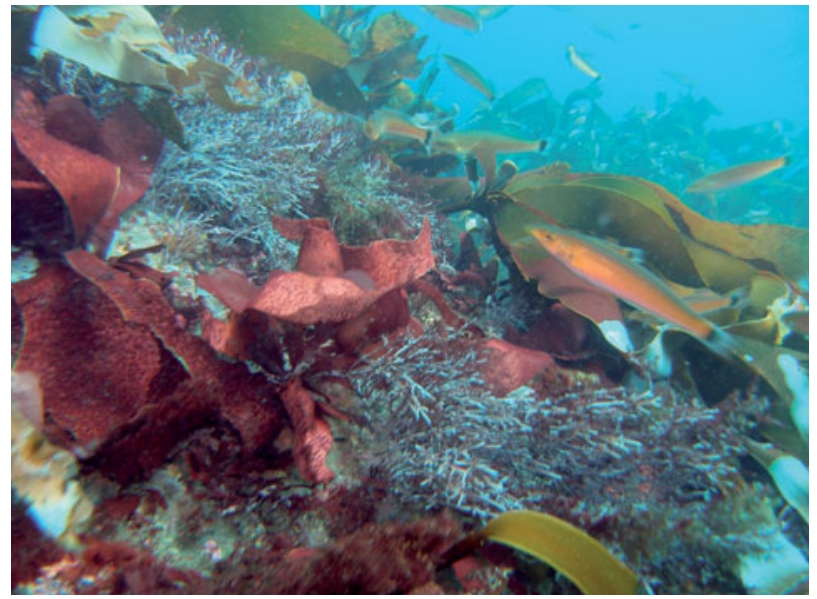

Foliose algae at Naples Reef, off Santa Barbara, California, USA.

Photo: R. J. Miller

\section{INTRODUCTION}

Macroalgae are important primary producers in shallow coastal marine habitats worldwide (Mann 1973, Marsh 1976) and can enter the food chain locally (Mann 1988, Duggins et al. 1989, Page et al. 2008) or be exported as detritus to nearby deep water (Vetter 1995, Harrold et al. 1998, Vetter \& Dayton 1999), intertidal (Dugan et al. 2003), and terrestrial habitats (Polis \& Hurd 1996, Polis et al. 2004). Macroalgae are most prolific in temperate regions, where large, conspicuous kelps dominate rocky reef habitats. Not surprisingly, most studies of primary production by macroalgae on temperate reefs have focused on kelps, which are among the 
most productive autotrophs in the world (Mann 2000). Much less is known about rates of primary production in smaller species of macroalgae, which are ubiquitous on shallow reefs in both temperate and tropical regions. Many of these smaller forms support diverse assemblages of invertebrate grazers (reviewed by Hatcher $1988,1990)$, but it is unclear whether their rates of primary production are sufficient to support the energetic needs of the animals that they harbor.

Dense mats of low-lying algae commonly referred to as algal turfs and looser aggregations of taller foliose and coarsely branching algae form conspicuous and distinct assemblages on temperate and tropical reefs. The turf growth form may vary in morphology and species composition and is thought to be a response or adaptation to stress, including grazing (Hay 1981), sedimentation (Airoldi 1998), physical disturbance (Sousa 1980), and, in the intertidal, desiccation (Hay 1981). Turfs are typically dominated by densely packed filamentous and finely branched algae, and may avoid invasion by taller foliose and coarsely branched algae by inhibiting their recruitment (Sousa et al. 1981, Airoldi \& Cinelli 1997), or physical and biological disturbance may suppress the growth of larger seaweeds that might otherwise outcompete them for space and light in less disturbed environments (Hay 1981, Robles \& Robb 1993). Biological disturbance such as grazing, in addition to shaping the turf growth form, may also enhance their productivity (Carpenter 1981).

The relative contribution of turf and foliose algal assemblages to the productivity of reef communities is unclear. Based on the generally positive correlation between canopy height and production (Jokiel \& Morrissey 1986), one might expect foliose assemblages to be more productive than turfs. Nonetheless, algal turfs are highly productive on tropical reefs (Carpenter 1986, Adey \& Goertemiller 1987, Hatcher 1988), supporting diverse and abundant assemblages of grazers. Mass-specific productivity of filamentous and finelybranched species that make up turfs is often higher than that of more robust foliose macroalgae, due to their higher surface-to-volume ratios (Littler \& Arnold 1982, Steneck \& Dethier 1994). Algal turfs, however, are often described as communities under stress that grow slowly, a view consistent with experimental work that has shown some turf species to be more productive when growing outside the turf matrix (e.g. Hay 1981, Taylor \& Hay 1984).

The extent to which turf and foliose algae contribute to secondary production is complicated by their dual role as a food source and as a habitat for animals. Macroalgae often harbor diverse and abundant communities of macrofauna that graze on them, depend on them for structural habitat, or both (e.g. Duffy 1990, Hacker \& Steneck 1990, Taylor 1998). Amphipods, for example, may choose algal habitats based solely on the architecture of the algae rather than their food value, with finely-branched and filamentous species preferred over species with foliose or leathery morphologies (Hacker \& Steneck 1990). Alternatively, some amphipods graze on specific species of macroalgae or on epiphytic microalgae (Hay et al. 1990). Regardless of the specific resources that macroalgae provide to the animals living within them, they are important habitats for macrofauna, which in turn are important food sources for fishes and other predators (Holbrook et al. 1997, Hobson \& Chess 2001).

In the present study we compared the community structure and productivity of a foliose algal assemblage to that of an algal turf assemblage on a shallow subtidal reef in southern California. We tested 3 primary hypotheses: (1) turf assemblages are maintained by recruitment inhibition of foliose species; (2) foliose assemblages, in accordance with their greater canopy height, are more productive on an areal basis than turf assemblages, but turfs are more productive than foliose assemblages on a biomass-specific basis; and (3) turfs support a greater biomass of macrofauna compared to foliose assemblages.

To test Hypothesis 1, we determined the species composition of the 2 assemblages in order to evaluate whether turfs were more likely maintained by recruitment inhibition of larger foliose species or by herbivory and disturbance depressing the size of canopy-forming species. If recruitment inhibition was the main mechanism maintaining turfs, we expected turfs to be a unique assemblage with the dominant foliose species excluded, whereas substantial species overlap between turf and foliose assemblages would provide evidence that the size of foliose species was depressed in turfs. To test Hypothesis 2, we assessed rates of gross primary production (GPP) and biomass-specific production by turf and foliose assemblages. To test Hypothesis 3, we quantified the abundance and biomass of macrofauna in the 2 assemblages and evaluated whether algal productivity in each was sufficient to support their resident macrofauna by measuring rates of net primary production (NPP), net community production (NCP), and community respiration (CR). These measurements allowed us to compare how much carbon was produced versus respired in each assemblage, and to determine how much organic carbon was available for export and/or consumption.

\section{MATERIALS AND METHODS}

Study site. The study was conducted at Naples Reef, a shale outcrop off the coast of Santa Barbara, California, USA $\left(34^{\circ} 25^{\prime} \mathrm{N}, 119^{\circ} 57^{\prime} \mathrm{W}\right.$; see Ebeling et al. 1980 
for detailed site description). Turf was defined as distinct mats of low-growing algae $<5 \mathrm{~cm}$ canopy height. Foliose assemblages were taller, bushier canopies, generally $>10 \mathrm{~cm}$ high. Both assemblages were morphologically distinct and have been identified as such in past work at this site (Laur \& Ebeling 1983). Giant kelp Macrocystis pyrifera, which is often considered the dominant benthic autotroph in this system (reviewed by Foster \& Schiel 1985, Graham et al. 2007) and which is capable of suppressing understory algae through shading (Reed \& Foster 1984), was sparse at Naples Reef during our study.

Sampling design. We compared the species composition and metabolism of foliose and turf algal assemblages along $10 \mathrm{~m}$ long transects placed at 10 to $12 \mathrm{~m}$ depth. Each transect traversed a single type of assemblage (turf or foliose) and was separated from other transects by at least $5 \mathrm{~m}$. Productivity measurements were simultaneously made at midday at 2 random positions along one transect traversing turf assemblages and a second transect traversing foliose assemblages. Subsequently all epifauna and macroalgae at each productivity measurement location were harvested for biomass and community composition estimates (details below). Data were collected on 7 dates during November and December 2006 for a total of 7 pairs of measurements for each of the 2 assemblages. Due to problems in sampling, however, the actual number of measurements totaled 12 for the foliose assemblages and 13 for turfs.

Productivity measurements: Primary production and respiration of the benthos were measured in situ as changes in oxygen in closed chambers that covered $0.1 \mathrm{~m}^{2}$ of the bottom $(25 \times 40 \mathrm{~cm})$. The chambers were tunnel-shaped, with end walls made of clear rigid acrylic and an open bottom framed by fiberglass-reinforced plastic (Fig. 1). Flexible teflon sheeting (Tefzel, DuPont) was stretched over the side walls of the frame and held in place by a nylon gasket. This flexibility permitted wave energy to be transmitted through the walls of the chambers, allowing algae inside to oscillate naturally with wave-generated flow (sensu Gust 1977, Malan \& McLachlan 1991, Yates \& Halley 2003). Chamber volume was 451 , and was measured for each chamber for production calculations. A battery-powered submersible pump (Rule 500 baitwell pump, 18901 $\mathrm{h}^{-1}$ ) circulated the water within each chamber to ensure mixing of oxygen and prevent mass-transfer limitation of algal photosynthesis. The chambers were sealed against the bottom with a weighted flexible plastic skirt. Observations using rhodamine dye indicated that this made a highly effective seal. Selfcontained optical probes (D-Opto, ENVCO) logged dissolved oxygen concentration and temperature inside the chambers once per minute.

Chambers were covered with blackout cloth for a dark incubation of $\sim 20$ min following a light incubation of $\sim 30 \mathrm{~min}$, durations that were sufficient to show distinct slopes in oxygen change. Following the dark incubation, insecticide (Triazicide, 0.5\% LambdaCyhalothrin, United Industries) was injected into the chambers to kill animals, allowing estimation of NPP from the subsequent rate of change in oxygen concentration. Insecticide concentration in the chambers was $\sim 1.9$ ppm; laboratory tests showed that this was sufficient for near-instantaneous death of small crustaceans and polychaete worms. Lambda-cyhalothrin is a synthetic pyrethroid which has low phytoxicity (DuPont Corp. pers. comm.) and has no effect on algal photosynthesis (Hill et al. 1994, Farmer et al. 1995). To confirm this we tested the effects of Triazicide on the photosynthetic rate of the 2 most abundant species of foliose algae, Rhodymenia californica and Chondracanthus corymbiferus. Individuals of these 2 species were carefully detached from the substrate and placed in polyethylene bags containing oxygen probes. Half the bags were injected with Triazicide in the same concentration used in the chambers. Bags were incubated in situ for $20 \mathrm{~min}$ in the light and 20 min in the dark. Mass-specific NPP was calculated and the effects of Triazicide on NPP were compared for each species with a $t$-test. We found no evidence of an effect of Tri-

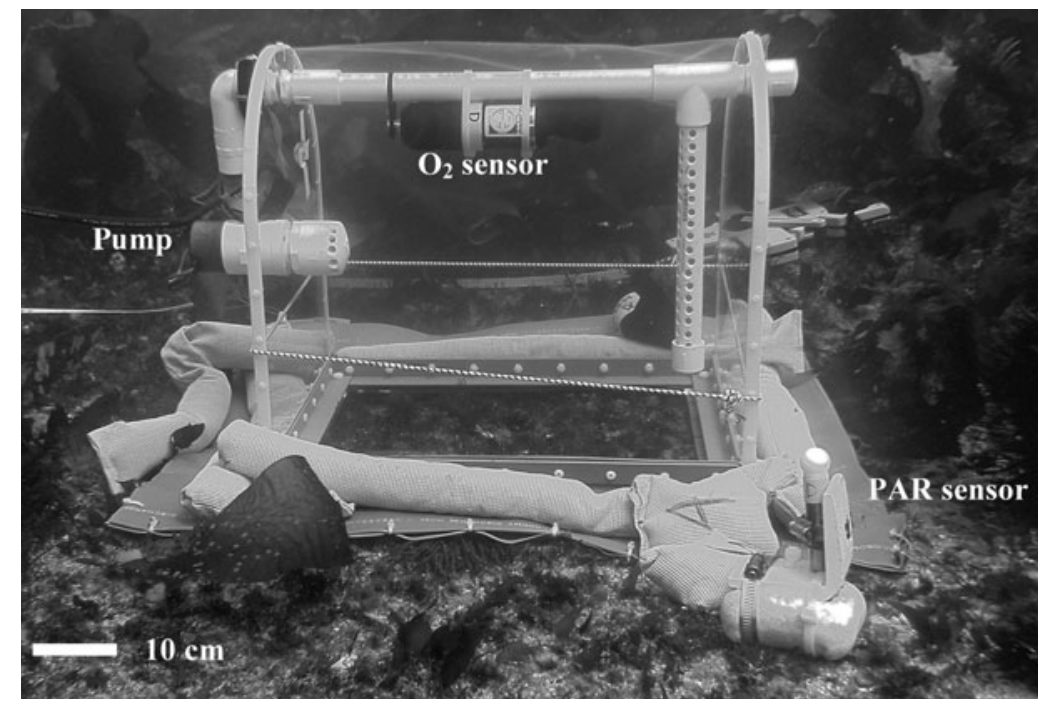

Fig. 1. Chamber setup on turf assemblage. The pump at left drives water through the pipe extending across the top of the chamber, and out the diffuser on the right side. An optical oxygen probe is secured to the top pipe. The plastic skirt is weighted with bags filled with lead shot 
azicide on net photosynthesis of Rhodymenia californica (mean $\pm \mathrm{SE}=0.12 \pm 0.08$ and $0.13 \pm 0.08 \mathrm{mmol} \mathrm{O}_{2}$ $\mathrm{g}^{-1}$ dry mass for control and poison treatments, respectively; $t_{0.05(4)}=0.07, \mathrm{p}=0.95$ ) or Chondracanthus corymbiferus $\left(0.08 \pm 0.02\right.$ and $0.07 \pm 0.02 \mathrm{mmol} \mathrm{O}_{2} \mathrm{~g}^{-1}$ dry mass for control and poison treatments, respectively; $t_{0.05(11)}=-0.29, \mathrm{p}=0.8$ ).

To determine whether photosynthetic rates varied due to natural variability in light levels, we measured bottom irradiance ( 400 to $700 \mathrm{~nm}$, frequency $=1 \mathrm{~s}$ ) during the incubations using logging photosynthetically active radiation (PAR) meters with hemispherical collectors (MKV-L, Alec Electronics) mounted on the bottom near the chambers. The collectors were $\sim 10 \mathrm{~cm}$ above bottom. PAR data were averaged over incubations for analysis.

Community structure and biomass: After incubations were completed, the benthos in the area enclosed by the chambers was collected by gently scraping algae and other material from the bottom and vacuuming it into a fine mesh bag using an airlift (e.g. Coyer et al. 2000). Macroalgae were separated from animals and other material in the laboratory and sorted by taxon. Epiphytes, which were all minute, were not identified. The algae were weighed and dried at $60^{\circ} \mathrm{C}$ to obtain dry weight. Subsamples of dried tissue for each algal taxon were ground and analyzed for carbon content using an automated organic elemental analyzer (Carlo-Erba Flash EA 1112 series, Thermo-Finnigan Italia), and these values were used to convert dry mass to carbon mass. Macroinvertebrates and associated sediment and debris were fixed in formalin for $2 \mathrm{~d}$ before being transferred for storage in $70 \%$ ethanol. This method of preservation does not significantly affect measurements of biomass (Gaston et al. 1996). These samples were sieved at $0.25 \mathrm{~mm}$, split as necessary, and sorted under a dissecting microscope. Macroinvertebrates were separated into major taxa (generally phylum), counted, dried at $60^{\circ} \mathrm{C}$, weighed, and combusted to obtain ash-free dry weight.

To provide a regional context for our experimental results, we analyzed data on the abundance of turf and foliose algal assemblages at Naples Reef and 10 other reef sites in the Santa Barbara Channel, collected by the Santa Barbara Coastal Long Term Ecological Research program over $9 \mathrm{yr}$ (http://sbc.lternet.edu/). Data on the percent of rocky substrate covered by these 2 algal assemblages were collected annually during the summers of 2000 to 2008 along 39 fixed $40 \times$ $2 \mathrm{~m}$ transects that were distributed among the 11 sites. These data allowed the assessment of the relative abundance and interannual variability of turf and foliose assemblages at a regional scale, which enabled us to estimate the relative productivity of each assemblage across the 11 sites.
Data analysis. We compared differences in algal community composition by analyzing differences in the biomass of species found in foliose and turf assemblages with canonical analysis of principal coordinates (CAP), using a permutation test of significance, and the leave-one-out approach to estimate goodness of fit of the groups. Correlation coefficients of the constrained canonical axis with the original taxonomic categories were used to identify the species most influencing the ordination (Anderson \& Robinson 2003, Anderson \& Willis 2003).

Production and respiration rates were calculated by plotting oxygen concentration over incubation time, fitting a linear regression line to the data, and using the regression equation to calculate hourly rates of oxygen change. GPP was calculated as the sum of oxygen produced in the light and that consumed by respiration in the dark prior to the pesticide treatment. NCP was estimated as oxygen production in the light incubation without pesticide. NCP represents production over and above all respiration, including animal respiration, and as such indicates the trophic status of the community, i.e. whether it is net autrophic, producing biomass that could be consumed or exported, or net heterotrophic, requiring input of allochthonous carbon to balance respiration. Oxygen consumption in the dark incubation without insecticide was used as an estimate of CR. NPP was taken to be oxygen produced in the light after insecticide treatment, which we assume eliminated animal respiration (some small component of animal respiration probably remained, so like most estimates of aquatic NPP, these are likely underestimates). All rates were calculated on a perarea and per-carbon biomass basis (for GPP and NPP) for analysis.

Turnover times of the biomass of the algal assemblages were calculated for each chambered plot as the ratio of total algal biomass to NPP. For these estimates, total algal biomass was expressed in $\mathrm{mgC} \mathrm{m}^{-2}$ and NPP was expressed in $\mathrm{mgC} \mathrm{m}{ }^{-2} \mathrm{~d}^{-1}$, which was obtained assuming a photosynthetic quotient of 1 (following Rosenberg et al. 1995) and a $12 \mathrm{~h}$ light:12 h dark photoperiod.

To determine which assemblage was more productive on Naples Reef, we compared areal productivity and metabolism (GPP, NPP, NCP, CR in $\mathrm{mmol} \mathrm{O}_{2} \mathrm{~m}^{-2}$ $\mathrm{h}^{-1}$ ), and carbon biomass-specific productivity rates in $\mathrm{mmol} \mathrm{O}_{2}$ (g macroalgal carbon mass) $)^{-1} \mathrm{~h}^{-1}$ of the 2 algal assemblages in separate analyses using a mixed-model ANOVA. Assemblage type (foliose and turf) was treated as a fixed factor and sampling date as a random factor. To estimate whether assemblages were net heterotrophic, we used $t$-tests to compare mean NCP with a hypothesized mean of zero. We compared macrofaunal density and biomass between the 2 assemblages using 


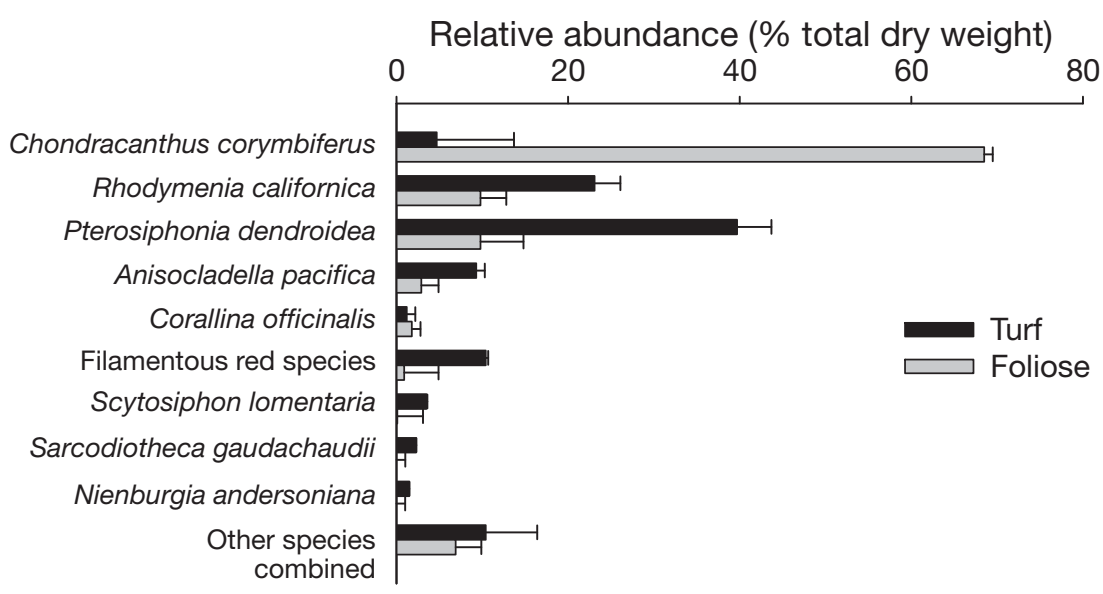

Fig. 2. Relative abundance of species in foliose and turf algal assemblages by percentage of total dry weight (mean +SE). Data are from $25 \times 40 \mathrm{~cm}$ incubation plots (n = 12 and 13 for foliose and turf, respectively). Species with $<1 \%$ of total dry weight on average are grouped under other species combined, which comprises 13 species for each assemblage single factor ANOVA. Levene's test was used to test for heteroscedasticity, and data were log-transformed if needed to meet ANOVA assumptions. Least squares regression was used to evaluate the relationship between carbon-specific NPP in mmol $\mathrm{O}_{2}$ (g macroalgal carbon mass $)^{-1} \mathrm{~h}^{-1}$ and mean light levels during our

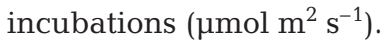

If the macrofauna relies on macroalgae for food, then we expect a positive relationship between productivity and macrofaunal abundance, as has been shown for coral reef herbivores (Russ 2003). Least squares regression was used to examine relationships between macrofaunal abundance (biomass and density) and productivity (NPP).

\section{RESULTS}

\section{Community structure}

We recorded 25 taxa of macroalgae across both assemblages; 9 taxa made up 86 and $93 \%$ of the biomass in turf and foliose assemblages, respectively (Fig. 2). Species richness was similar in both assemblages (mean $\pm \mathrm{SE}=7.8 \pm 1$ for foliose algae and $8.0 \pm$ 1 for turfs), and $80 \%$ of the species were found in both assemblages. The species composition of these 2 func- tionally different assemblages varied mainly in the identity of their dominant species: Chondracanthus corymbiferus, a large, broad-bladed red alga, accounted for nearly $70 \%$ of the biomass in foliose assemblages, while the small, finely branched red alga Pterosiphonia dendroidea was the dominant species in turfs, composing nearly $40 \%$ of the biomass (Fig. 2). Rhodymenia californica, a coarsely branched red alga, was abundant in both assemblages, forming large bushy clumps in the foliose assemblages and a lowgrowing component of the mat in turf assemblages. $C$. corymbiferus also occurred in turfs as small individuals, and $P$. dendroidea, which is always small, occurred sparsely in foliose assemblages. Four of the 5 taxa that were unique to a single assemblage occurred in only one sample. Microcladia coulteri, a small branching red alga, was the exception; it occurred only in turfs and was represented in $50 \%$ of the turf samples.

CAP analysis showed that foliose and turf assemblages were significantly different $(p=0.0001$ from 9999 permutations) (Fig. 3). Correlations of the canonical axes revealed that 3 species largely delineated the 2 assemblages: Chondracanthus corymbiferus (canonical correlation $=-0.87)$, Pterosiphonia dendroidea (0.69), and Microcladia coulteri (0.54). Leave-one-out analysis of the 2 assemblages showed a high classification accuracy of $96 \%$ overall (Table 1 ).
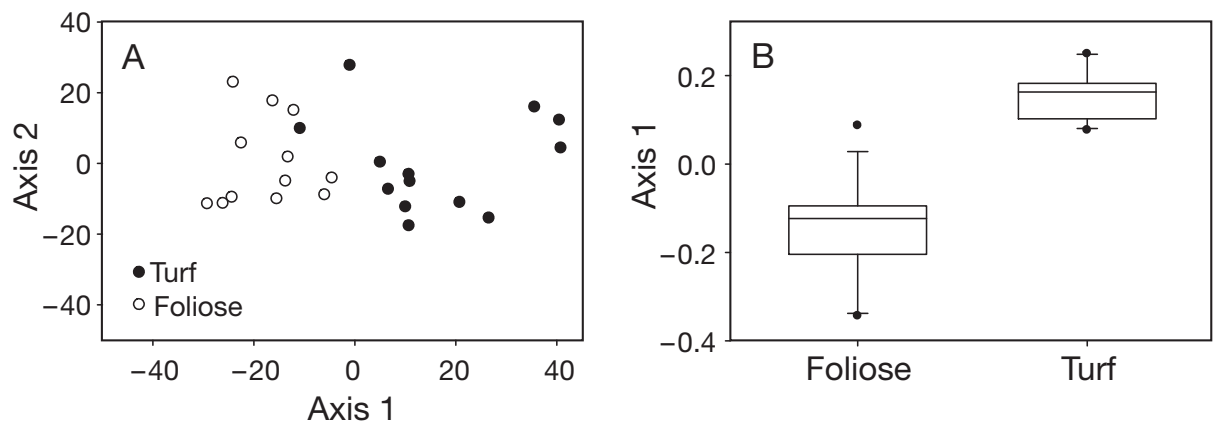

Fig. 3. (A) Unconstrained metric multidimensional scaling plot of Bray-Curtis distances between sample quadrats. (B) Boxplot of the canonical axis (the single axis produced for $\mathrm{n}=2$ groups) values for the 2 groups. Box boundaries indicate the 25th and 75th percentiles, and the line within the box marks the median. Whiskers above and below the box indicate the 90th and 10th percentiles 
Table 1. Leave-one-out allocation of plots to groups (foliose versus turf) in canonical analysis of principal coordinates analysis. Classifications were correct in $96 \%$ of cases

\begin{tabular}{|lcccc|}
\hline Group & Foliose & Turf & Total $\mathrm{n}$ & \% correct \\
\hline Foliose & 12 & 1 & 13 & 92.3 \\
Turf & 0 & 12 & 12 & 100 \\
\hline
\end{tabular}

The differences in species dominance and growth forms were accompanied by pronounced differences in total biomass between the 2 assemblages. Algal biomass, as dry weight, was more than 4 times higher in foliose assemblages compared with turfs (Fig. 4). When compared in units of carbon, these differences were even greater, with foliose assemblages containing an average of 7 times more carbon per area of reef than turfs (Fig. 4). This reflected a significantly higher percentage carbon by dry weight in foliose algae compared with turfs $(21 \pm 1 \%$ for foliose algae and $13 \pm 1 \%$ for turfs; $\left.F_{1,23}=63.7, \mathrm{p}<0.0001\right)$. Turfs had a significantly lower $\mathrm{C}: \mathrm{N}$ atomic ratio than foliose algae $(6.4 \pm$ 0.2 versus $11.2 \pm 1$, respectively; $F_{1,23}=55.3, \mathrm{p}<0.0001$ ).

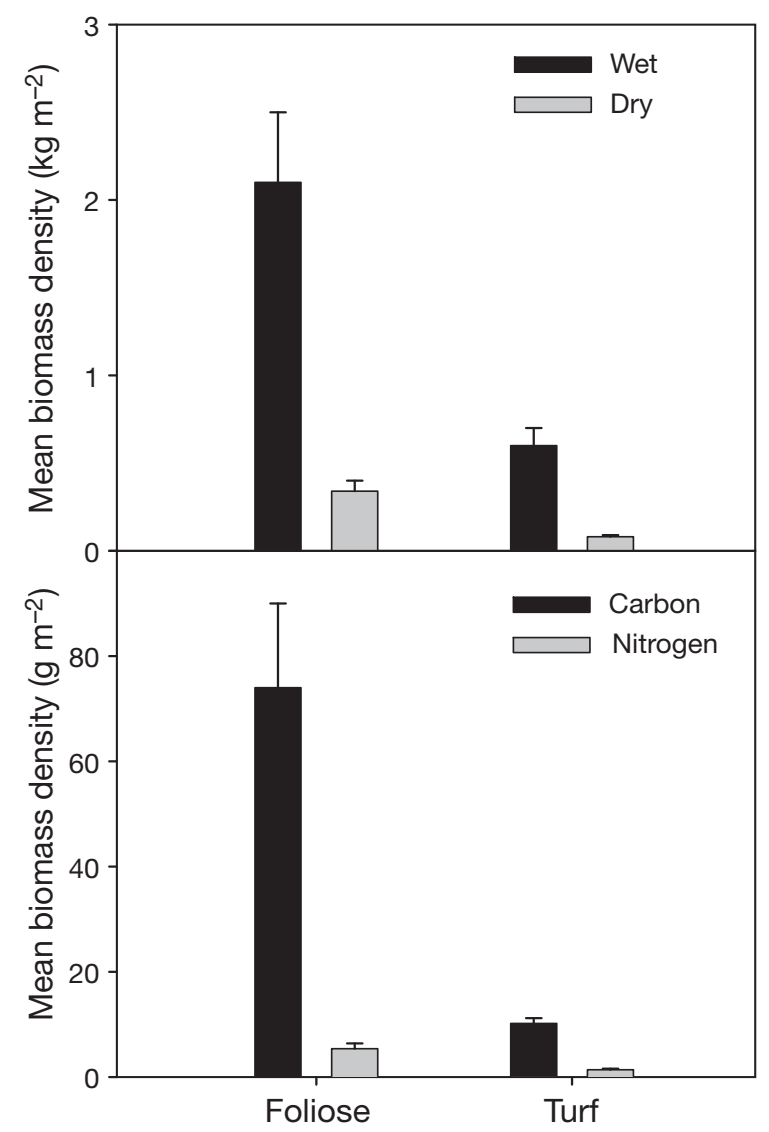

Fig. 4. Mean biomass density (+SE) of turf and foliose macroalgae in $25 \times 40 \mathrm{~cm}$ incubation plots $(\mathrm{n}=12$ and 13 for foliose and turf, respectively), expressed as wet mass, dry mass, carbon mass and nitrogen mass per square meter

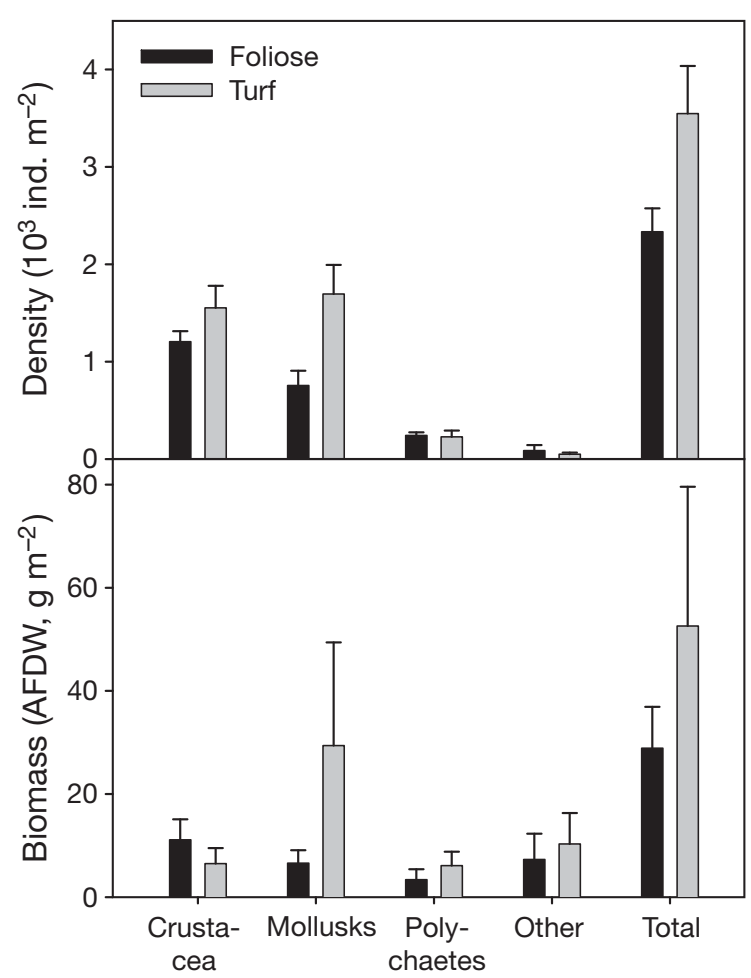

Fig. 5. Mean (+SE) macrofauna density (top) and biomass (bottom) in foliose and turf algal assemblages ( $\mathrm{n}=12$ and 13 for foliose and turf, respectively). AFDW: ash-free dry weight

The macrofauna of both foliose and turf communities were dominated by crustaceans and mollusks, followed by polychaetes (Fig. 5). Smaller numbers of echinoderms and other taxa were also present. Total macrofaunal abundance was significantly greater in turf assemblages (3548 \pm 380 ind. $\mathrm{m}^{-2}$ for turf, $2335 \pm$ 370 ind. $\mathrm{m}^{-2}$ for foliose; $F_{1,23}=5.21, \mathrm{p}=0.03$ ). Although mean ash-free dry weight of macrofauna in turfs was nearly double that of foliose assemblages, the difference was not statistically significant $\left(52.6 \pm 27 \mathrm{~g} \mathrm{~m}^{-2}\right.$ for turf, $28.9 \pm 8 \mathrm{~g} \mathrm{~m}^{-2}$ for foliose; $F_{1,23}=0.8, \mathrm{p}=0.4$ ).

Percent cover data collected from 11 sites in the Santa Barbara Channel over a 9 yr period showed that both turf and foliose assemblages occupied a significant fraction of the rocky habitat on reefs in this region. The 2 assemblages typically co-occurred, with the size of each assemblage ranging from the scale of centimeters to 10 s of meters. Foliose assemblages were 3 times more abundant than turfs when averaged across all sites and years $(27.2 \pm 2 \%$ for foliose and $9.9 \pm 1 \%$ for turf; $\left.F_{1,76}=48.13 \mathrm{p}<0.0001\right)$. Interestingly, turf assemblages appeared to be less persistent in time as they displayed significantly greater interannual variability than foliose assemblages. The mean coefficient of variation for percent cover calculated among years for each transect averaged $100.1 \pm 6.9 \%$ for turf and only $72.3 \pm 5.3 \%$ for foliose algae $\left(F_{1,76}=10.23 p=0.0020\right)$. 


\section{Production and respiration rates}

Bottom irradiance averaged $145.3 \pm 15 \mu \mathrm{mol}$ photons $\mathrm{m}^{-2} \mathrm{~s}^{-1}$ during the productivity incubations. There was no relationship between carbon-specific NPP and mean irradiance during the incubations for either assemblage $\left(\mathrm{r}^{2}<0.1, \mathrm{p}>0.14\right)$, indicating that both assemblages experienced saturating irradiances when the productivity measurements were made.

\section{Areal rates}

By all measures, mean areal production rates of foliose assemblages were significantly higher than those of turf assemblages. GPP was more than twice as high and NPP was about 3 times higher in foliose communities compared with turfs (Fig. 6, Table 2). Sampling Date had a significant effect on NPP, but this effect was not seen on other rates (Table 2). CR rates of the 2 assemblages were similar (Table 2), which when coupled with GPP led to significantly lower NCP by turf compared to foliose assemblages (Fig. 6, Table 2). Mean NCP of foliose understory was not significantly different from zero $\left(t_{0.05}(12)=-1.0, \mathrm{p}=0.3\right)$, whereas mean NCP of turfs was significantly less than zero at $-6.9 \pm 1.7 \mathrm{mmol} \mathrm{O}_{2} \mathrm{~m}^{-2} \mathrm{~h}^{-1}\left(t_{0.05(11)}=-4.1, \mathrm{p}=0.001\right)$, indicating that turfs were net heterotrophic.

Neither density nor biomass of macrofauna were significantly related to NPP of the 2 algal assemblages $\left(\mathrm{r}^{2}<0.05, \mathrm{p}>0.3\right.$ for both cases $)$, as might be expected if macrofauna were using the algae as food.

Carbon-specific productivity rates and turnover times

Although turfs were less productive than foliose assemblages on an areal basis, they were significantly more productive than foliose assemblages on a carbon biomass basis. Carbon-specific rates of NPP and

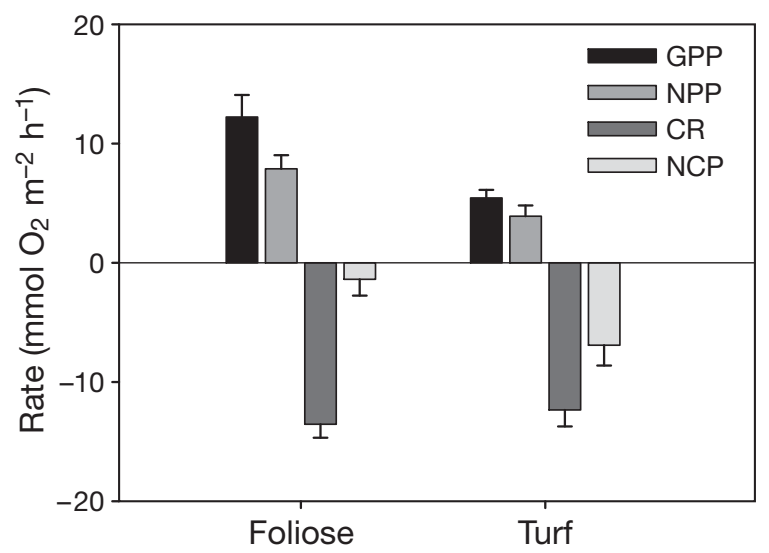

Fig. 6. Areal rates of production and respiration for foliose and turf macroalgal assemblages. GPP: gross primary production; NPP: net primary production; CR: community respiration; NCP: net community production. See Table 2 for sample sizes
GPP were approximately 2 and 3 times higher, respectively, in turf compared to foliose assemblages (Fig. 7, Table 3). As was found with areal estimates of NPP, carbon-specific rates of NPP varied significantly among sampling dates (Table 3). Mean turnover times of the assemblages differed substantially ( $39 \pm 11 \mathrm{~d}$ for turf vs. $126 \pm 59 \mathrm{~d}$ for foliose assemblages), though not significantly $\left(F_{1,21}=1.62, \mathrm{p}=0.22\right)$.

\section{DISCUSSION}

\section{Lack of recruitment inhibition}

We found no evidence to support the hypothesis that turf assemblages are maintained by recruitment inhibition of foliose species. Instead, we found high species overlap between the 2 assemblages, which differed distinctly with respect to species dominance and a shift in the morphology of many of the shared taxa to smaller sizes in turf assemblages. Turf and foliose assemblages on temperate rocky reefs appear strikingly different to the observer, and have often been considered distinct (e.g. Hixon 1980, Underwood et al. 1991, Holbrook et al. 1997, Westphalen \& Cheshire 1997, Fowler-Walker \& Connell 2002, Copertino et al. 2006). Dense, mat-like turfs at Naples Reef typically

Table 2. ANOVA on benthic gross primary production (GPP), net primary production (NPP), community respiration (CR), and net community production (NCP) rates in $\mathrm{mmol} \mathrm{O}_{2} \mathrm{~m}^{-2}$ $\mathrm{h}^{-1}$. Assemblage has 2 fixed levels, Foliose or Turf, and sampling Date was treated as a random factor. Sample sizes for GPP and NPP were smaller than those for CR and NCP due to lost incubations. Significant values are indicated in bold

\begin{tabular}{|lcccc|}
\hline Source & df & SS & $F$ & $\mathrm{p}$ \\
\hline GPP $(\mathrm{n}=21)$ & & & & \\
Assemblage & 1 & 202.4 & 5.6 & $\mathbf{0 . 0 3}$ \\
Date & 1 & 0.1 & 0.002 & 0.96 \\
Assemblage $\times$ Date & 1 & 0.4 & 0.01 & 0.92 \\
Residual & 20 & 724.9 & & \\
NPP (n = 20) & & & & \\
Assemblage & 1 & 113.2 & 10.1 & $\mathbf{0 . 0 1}$ \\
Date & 1 & 61.1 & 5.4 & $\mathbf{0 . 0 3}$ \\
Assemblage $\times$ Date & 1 & 9.7 & 0.9 & 0.4 \\
Residual & 19 & 213.3 & & \\
CR (n =22) & & & & \\
Assemblage & 1 & 0.74 & 0.02 & 0.9 \\
Date & 1 & 7.01 & 0.20 & 0.7 \\
Assemblage $\times$ Date & 1 & 7.35 & 0.21 & 0.7 \\
Residual & 21 & 746.5 & & \\
NCP $(\mathrm{n}=22)$ & & & & \\
Assemblage & 1 & 183.9 & 5.8 & $\mathbf{0 . 0 2}$ \\
Date & 1 & 6.2 & 0.2 & 0.7 \\
Assemblage $\times$ Date & 1 & 8.5 & 0.27 & 0.6 \\
Residual & 21 & 661.4 & & \\
\hline
\end{tabular}




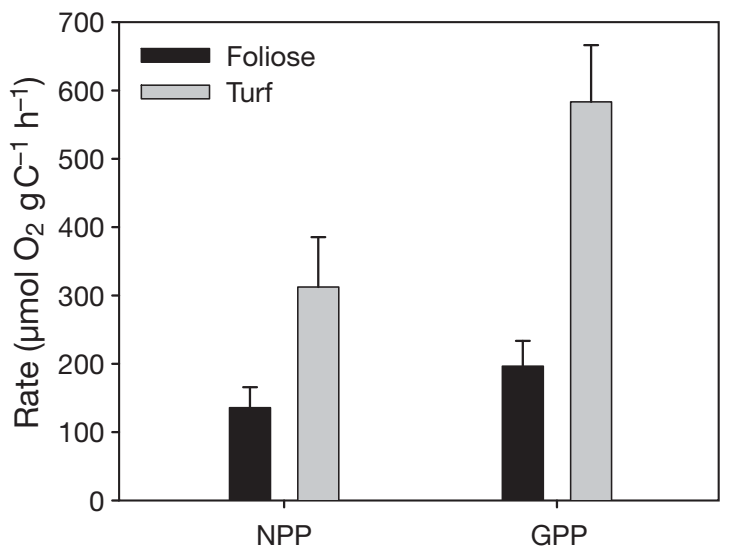

Fig. 7. Carbon mass-specific rates of net primary production (NPP) and gross primary production (GPP) for foliose and turf macroalgal assemblages. See Table 3 for sample sizes

Table 3. ANOVA on carbon biomass-specific rates of gross primary production (GPP) and net primary production (NPP), in $\mu \mathrm{mol} \mathrm{O}_{2} \mathrm{gC}^{-1} \mathrm{~h}^{-1}$. Assemblage has 2 fixed levels, Foliose or Turf, and sampling Date was treated as a random factor. Significant values are indicated in bold

\begin{tabular}{|lcccc|}
\hline Source & df & SS & $F$ & $p$ \\
\hline GPP $(\mathrm{n}=20)$ & & & & \\
$\quad$ Assemblage & 1 & 891411.1 & 19.9 & $\mathbf{0 . 0 0 0 3}$ \\
Date & 1 & 136809.9 & 3.1 & 0.1 \\
Assemblage $\times$ Date & 1 & 109100.6 & 2.4 & 0.1 \\
Residual & 19 & 849403.9 & & \\
NPP $(\mathrm{n}=20)$ & & & & \\
Assemblage & 1 & 206356.3 & 9.9 & $\mathbf{0 . 0 1}$ \\
Date & 1 & 195578.2 & 9.3 & $\mathbf{0 . 0 1}$ \\
Assemblage $\times$ Date & 1 & 71932.4 & 3.4 & 0.1 \\
Residual & 19 & 397826.5 & & \\
\hline
\end{tabular}

extend no more than 2 to $3 \mathrm{~cm}$ above the seabed, whereas lush foliose assemblages have high bushy canopies 10 to $40 \mathrm{~cm}$ high. In the present study this height difference was driven by the dominance of the large red alga Chondracanthus corymbiferus in foliose assemblages and the small, finely-branched Pterosiphonia dendroidea and Microcladia coulteri in turfs, as reflected by results of the CAP analysis. The difference in the height of the 2 assemblages was also driven by changes in morphology of the same taxa across assemblages. For example, Rhodymenia californica was abundant in both assemblages, but it formed large bushy clumps in the foliose assemblages, whereas it presented a low-growing morphology in the turf mat. C. corymbiferus also occurred in turfs as small individuals and $P$. dendroidea, which is always small, occurred sparsely in foliose assemblages. While these findings reinforce the concept of turfs as a growth form or functional group rather than a distinct assemblage (Lewis et al. 1987, Hay et al. 1990), they also support the idea that turfs may be maintained by processes that stunt dominant foliose species or restrict their population structure to juveniles only, thus facilitating smaller species such as $P$. dendroidea. The common occurrence of $C$. corymbiferus in turf assemblages suggests that recruitment of foliose species was not suppressed in the turf assemblages at Naples Reef, as has been suggested for other systems (Sousa et al. 1981, Airoldi 1998).

Physical disturbance can probably be ruled out as a dominant controller of the biomass of algae growing in turfs in the present study. The greatest physical disturbance to macrophyte assemblages on shallow reefs off southern California occurs during fall and winter, when storm waves periodically batter the coast (Reed et al. 2008). The timing of the present study, in November-December 2006, was before the year's first large storm waves affected Naples Reef. A more likely form of disturbance controlling the biomass of algae in turfs was cropping by mobile consumers (Foster 1972, Lewis et al. 1987, Hacker \& Steneck 1990, Hay et al. 1990). Likely candidates here are surfperches (family Embiotocidae), which are abundant on Naples Reef and other reefs in this region. Several of these species forage intensively and specifically on turfs by biting off clumps of algae, sediment, and other debris that accumulates in the mat, and orally winnowing through it, retaining macrofauna and spitting out most of the algae and other material (Laur \& Ebeling 1983). In this way the standing crop of macroalgae in turfs may be suppressed not by grazing per se, but as collateral damage done by fishes foraging for macrofauna living in the turf. Apparent specialization of Microcladia coulteri to turf assemblages may indicate that this species benefits from turf cropping, perhaps through relief from competition for light by the stunting of foliose forms that would otherwise overtop and shade shorter forms (Wootton 1994).

\section{Productivity}

Our findings support the hypothesis that foliose assemblages are more productive than turf assemblages, due to their greater biomass per unit area and not because of greater production per unit biomass. Gross, net, and community production were greater per unit area of seafloor in foliose assemblages compared to turfs, which is consistent with the much larger standing crop (biomass) of foliose assemblages. In contrast, carbon-specific rates of GPP and NPP were greater in turf than foliose assemblages, corresponding with the higher surface to volume ratio of the dominant turf species, Pterosiphonia dendroidea, compared to the dominant foliose species, Chondracanthus 
corymbiferus (Littler \& Arnold 1982). Rates of primary production by macroalgae on temperate reefs vary over seasonal time scales (Heine 1983) and it is possible that the differences in production that we observed between foliose and turf assemblages might vary with the time of year. We view this as unlikely given the high species overlap between the 2 assemblages and the dependence of these species on common resources to fuel primary production.

The average carbon-specific production by turfs (400 $\mathrm{\mu mol} \mathrm{O} \mathrm{O}_{2} \mathrm{~g}^{-1} \mathrm{C} \mathrm{h}^{-1}$ ) would allow turf algae to double in biomass in approximately $1 \mathrm{mo}$, assuming such rates were maintained for the daylight period only.

Production rates for both the turf and foliose assemblages that we measured were similar to those found in other macroalgal communities. Assuming a photosynthetic quotient of unity and a $12 \mathrm{~h}$ daylength, we estimated mean NPP rates of $0.9 \pm 0.1 \mathrm{~g} \mathrm{C} \mathrm{m}^{-2} \mathrm{~d}^{-1}$ for foliose assemblages and $0.4 \pm 0.1 \mathrm{~g} \mathrm{C} \mathrm{m}^{-2} \mathrm{~d}^{-1}$ for turfs. Both values are within the range reported for macroalgal communities by Duarte \& Cebrian (1996), and that for the foliose assemblage is close to the median. Similar production values have been measured for turfs in temperate South Australia (Westphalen \& Cheshire 1997, Copertino et al. 2005), and although Copertino et al. (2005) found higher productivity rates for shallow (4 m depth) turfs (1.3 to $2.9 \mathrm{~g} \mathrm{C} \mathrm{m}^{-2} \mathrm{~d}^{-1}$ ), both studies concluded, like the present study, that foliose assemblages were more productive than turfs on an areal basis, 2 to 7 times higher in the case of Copertino et al. (2005). Moreover, the long-term data from 11 reefs in the Santa Barbara Channel indicate that foliose assemblages are approximately 3 times more abundant than turf assemblages, magnifying the difference in contribution to ecosystem productivity of the 2 assemblages.

On coral reefs, algal turfs can be important primary producers due to their high biomass-specific production rates (e.g. Carpenter 1986) and extensive grazing by fishes and echinoids, which represses foliose algae (Adey \& Steneck 1985, Carpenter 1986). Nevertheless, when they occur, foliose algae are likely more productive than turfs on tropical reefs (Hatcher 1988, 1990), as well as temperate reefs (Westphalen \& Cheshire 1997, Copertino et al. 2005, present study). In a study that compared productivity of coral reef turfs to foliose assemblages, the latter were on average 6 times more productive than turfs, and despite the greater abundance of turfs (30 vs. $8 \%$ cover for foliose algae), this disparity in areal productivity rates made foliose assemblages more important producers than turfs (Rogers \& Salesky 1981).

The C:N molar ratio of turfs was significantly lower than that of foliose assemblages (6.4 vs. 11.2, respectively). Atkinson \& Smith (1983) reported C:N ratios for benthic marine plants ranging from 6 to 60, with 20 as the median value. The low $\mathrm{C}: \mathrm{N}$ ratio of turfs compared with foliose assemblages is consistent with 2 explanations: (1) foliose macroalgae contain a large amount of structural carbon, compared to turf species, and (2) foliose macroalgae are nutrient-limited, compared to turfs. Both of these factors could have contributed to the higher $\mathrm{C}: \mathrm{N}$ ratios in foliose assemblages. Turfs were dominated by small, finely branching species, particularly Pterosiphonia dendroidea, that may have proportionally less structural carbon than foliose species. Low C:N ratios may also result from high nitrogen supplies. Benthic animals can be a significant source of nutrients to macroalgae, at times providing all the nitrogen the algae require (Bray et al. 1988, Taylor \& Rees 1998, Bracken et al. 2007). Turfs were replete with nitrogen-excreting macrofauna, and form dense, low-growing mats (typically less than $2 \mathrm{~cm}$ in our system). Therefore, plants within turfs may be in a better hydrodynamic position, likely within the benthic boundary layer as well as within a dense flowinhibiting mat, to take advantage of nitrogen produced in situ before it is swept away by currents (Carpenter \& Williams 1993, Hurd 2000).

\section{Secondary production}

Algal production was not a significant predictor of the abundance of macrofauna in the plots, as might be expected if macrofauna were relying on macroalgae for food (e.g. Russ 2003). Despite the lower production and biomass of turfs, they harbored greater numbers of macrofauna compared to foliose assemblages. This was reflected in the high respiration rates of turfs, and consequently low, negative net community production rates. These community production rates, moreover, are maximum estimates of daily rates, as nighttime respiration was not included in our calculations, although it may be significantly lower than daytime rates (Middelburg et al. 2005). Interpretation of NCP rates can be clouded by phase differences between the daily oscillations in production and respiration (Falter et al. 2001); however, the negative NCP rates and the relatively high macrofaunal densities and biomass levels in turf compared to foliose assemblages indicate that animal communities living in turfs cannot meet their carbon requirements using in situ production. Nevertheless, we lack species and diet data on the specific macrofauna sampled, and it is possible that a subset of herbivorous species were sustained by production within turfs.

The feeding modes of turf macrofauna are a means by which they can garner food resources from outside the environs of the turf. Many of the animals are either: 
(1) suspension feeders that rely mainly on phytoplankton and other seston for food (e.g. Holbrook et al. 1997), or (2) detritivores feeding on organic material exported from other areas. Both of these feeding modes, particularly suspension feeding, are common in the turf macrofaunal taxa (ibid). Some suspension feeders may rely on macroalgal detritus as well as on seston (Dunton \& Schell 1987, Duggins et al. 1989, Kaehler et al. 2000). Stable isotope analysis of reef suspension feeders in giant kelp forests off Santa Barbara, however, suggests that phytoplankton, rather than kelp or other macroalgal detritus, is their main source of dietary carbon (Page et al. 2008).

\section{CONCLUSIONS}

The distinctiveness of turf and foliose assemblages appears to be maintained by multiple dynamic processes and is not an inherent characteristic of their species composition. A shift in species dominance facilitated by the cropping of foliose forms by grazers is one likely maintenance mechanism. Variability in grazing pressure may allow turfs to evolve into foliose assemblages, significantly altering benthic primary and secondary production on reefs.

Acknowledgements. We thank S. Harrer, C. Nelson, A. Craig, L. Davenport, and N. Schooler for field and laboratory assistance. R. Zimmerman, R. Carpenter, S. Holbrook, R. Schmitt, and 3 anonymous referees provided helpful discussion. This work was supported by the National Science Foundation under grant nos. OCE 9982105 and OCE 0620276.

\section{LITERATURE CITED}

Adey WH, Goertemiller T (1987) Coral reef algal turfs: master producers in nutrient poor seas. Phycologia 26:374-386

Adey WH, Steneck RS (1985) Highly productive eastern Caribbean reefs: synergistic effects of biological, chemical, physical and geological factors. In: Reaka M (ed) The ecology of deep and shallow coral reefs. Symp Ser Undersea Res 2, NOAA, Rockville, MD

Airoldi L (1998) Roles of disturbance, sediment stress, and substratum retention on spatial dominance in algal turf. Ecology 79:2759-2770

Airoldi L, Cinelli F (1997) Effects of sedimentation on subtidal macroalgal assemblages: an experimental study from a Mediterranean rocky shore. J Exp Mar Biol Ecol 215:269-288

Anderson MJ, Robinson J (2003) Generalised discriminant analysis based on distances. Aust N Z J Stat 45:301-318

Anderson MJ, Willis TJ (2003) Canonical analysis of principal coordinates: a useful method of constrained ordination for ecology. Ecology 84:511-525

Atkinson MJ, Smith SV (1983) C:N:P ratios of benthic marine plants. Limnol Oceanogr 28:568-574

Bracken MES, Gonzalez-Dorantes CA, Stachowicz JJ (2007) Whole-community mutualism: associated invertebrates facilitate a dominant habitat-forming seaweed. Ecology 88:2211-2219
Bray RN, Miller AC, Johnson S, Krause PR, Robertson DL, Westcott AM (1988) Ammonium excretion by macroinvertebrates and fishes on a subtidal rocky reef in southern California. Mar Biol 100:21-30

Carpenter RC (1981) Grazing by Diadema antillarum (Philippi) and its effects on the benthic algal community. J Mar Res 39:749-765

Carpenter RC (1986) Partitioning herbivory and its effects on coral reef algal communities. Ecol Monogr 56:345-363

Carpenter RC, Williams SL (1993) Effects of algal turf canopy height and microscale substratum topography on flow speed profiles in a coral forereef environment. Limnol Oceanogr 38:687-694

Copertino M, Connell SD, Cheshire A (2005) The prevalence and productivity of turf-forming algae on a temperate subtidal coast. Phycologia 44:241-248

> Copertino MDS, Cheshire A, Watling JR (2006) Photoinhibition and photoacclimation of turf algal communities on a temperate reef, after in situ transplantation experiments. J Phycol 42:580-592

Coyer J, Steller D, Witman J (2000) The underwater catalog. A guide to methods in underwater research, 2nd edn. Shoals Marine Laboratory, Ithaca, NY

Duarte CM, Cebrian J (1996) The fate of autotrophic production in the sea. Limnol Oceanogr 41:1758-1766

> Duffy JE (1990) Amphipods on seaweeds: partners or pests? Oecologia 83:267-276

> Dugan JE, Hubbard DM, McCrary MD, Pierson MO (2003) The response of macrofauna communities and shorebirds to macrophyte wrack subsides on exposed sandy beaches of southern California. Estuar Coast Shelf Sci 58(Suppl): $25-40$

> Duggins DO, Simenstad CA, Estes JA (1989) Magnification of secondary production by kelp detritus in coastal marine ecosystems. Science 245:170-173

> Dunton KH, Schell DM (1987) Dependence of consumers on macroalgal (Laminaria solidungula) carbon in an arctic kelp community: $\delta^{13} \mathrm{C}$ evidence. Mar Biol 93:615-625

Ebeling AW, Larson RJ, Alevizon WS, Bray RN (1980) Annual variability of reef-fish assemblages in kelp forests off Santa Barbara, California. Fish Bull 78:361-377

Falter JL, Atkinson MJ, Langdon C (2001) Production-respiration relationships at different time-scales within the Biosphere 2 coral reef biome. Limnol Oceanogr 46:1653-1660

Farmer D, Maund SJ, Hill IR (1995) A comparison of the fate and effects of two pyrethroid insecticides (lambdacyhalothrin and cypermethrin) in pond mesocosms. Ecotoxicology 4:219-244

Foster MS (1972) The algal turf community in the nest of the ocean goldfish (Hypsypops rubicunda). Proc Int Seaweed Symp 7:55-60

Foster MS, Schiel DR (1985) The ecology of giant kelp forests in California: a community profile. US Fish and Wildlife Service Biol Rep 85(7.2), Washington, DC

Fowler-Walker MJ, Connell SD (2002) Opposing states of subtidal habitat across temperate Australia: consistency and predictability in kelp canopy-benthic associations. Mar Ecol Prog Ser 240:49-56

Gaston GR, Bartlett J, McAllister A, Heard R (1996) Biomass variations of estuarine macrobenthos preserved in ethanol and formalin. Estuaries 19:674-679

Graham MH, Vasquez J, Buschmann A (2007) Global ecology of the giant kelp Macrocystis: from ecotypes to ecosystems. Oceanogr Mar Biol Annu Rev 45:39-88

Gust G (1977) Turbulence and waves inside flexible-wall systems designed for biological studies. Mar Biol 42:47-53

> Hacker SD, Steneck RS (1990) Habitat architecture and the abundance and body size-dependent habitat selection of a 
phytal amphipod. Ecology 71:2269-2285

Harrold C, Light K, Lisin S (1998) Organic enrichment of submarine-canyon and continental-shelf benthic communities by macroalgal drift imported from nearshore kelp forests. Limnol Oceanogr 43:669-678

Hatcher BG (1988) Coral reef primary productivity: a beggar's banquet. Trends Ecol Evol 3:106-111

Hatcher BG (1990) Coral reef primary productivity: a hierarchy of pattern and process. Trends Ecol Evol 5:149-155

Hay ME (1981) The functional morphology of turf forming seaweeds: persistence in stressful marine habitats. Ecology 62:739-750

Hay ME, Duffy JE, Fenical W (1990) Host-plant specialization decreases predation on a marine amphipod: an herbivore in plant's clothing. Ecology 71:733-743

Heine JN (1983) Seasonal productivity of two red algae in a central California kelp forest. J Phycol 19:146-152

Hill IR, Shaw JL, Maund SJ (1994) Review of aquatic field tests with pyrethroid insecticides. In: Hill IR, Heimbach F, Leeuwangh P, Matthiessen P (eds) Freshwater field tests for hazard assessment of chemicals. CRC Press, Boca Raton, FL

> Hixon MA (1980) Competitive interactions between California reef fishes of the genus Embiotoca. Ecology 61:918-931

> Hobson ES, Chess JR (2001) Influence of trophic relations on form and behaviour among fishes and benthic invertebrates in some Californian marine communities. Environ Biol Fishes 60:411-457

Holbrook SJ, Schmitt RJ, Stephens JA (1997) Changes in an assemblage of temperate reef fishes associated with a climate shift. Ecol Appl 7:1299-1310

Hurd CL (2000) Water motion, marine macroalgal physiology, and production. J Phycol 36:453-472

Jokiel PL, Morrissey JI (1986) Influence of size on primary production in the reef coral Pocillopora damicornis and the macroalga Acanthophora spicifera. Mar Biol 91:15-26

Kaehler S, Pakhomov EA, McQuaid CD (2000) Trophic structure of the marine food web at the Prince Edward Islands (Southern Ocean) determined by $\delta^{13} \mathrm{C}$ and $\delta^{15} \mathrm{~N}$ analysis. Mar Ecol Prog Ser 208:13-20

Laur DR, Ebeling AM (1983) Predator-prey relationships in surfperches. Environ Biol Fishes 8:217-229

Lewis SM, Norns JN, Searles RB (1987) The regulation of morphological plasticity in tropical reef algae by herbivory. Ecology 68:636-641

Littler MM, Arnold KE (1982) Primary productivity of marine macroalgal functional-form groups from southwestern North America. J Phycol 18:307-311

Malan DE, McLachlan A (1991) In situ benthic oxygen fluxes in a nearshore coastal marine system: a new approach to quantify the effect of wave action. Mar Ecol Prog Ser 73: 69-81

> Mann KH (1973) Seaweeds: their productivity and strategy for growth. Science 182:975-981

Mann KH (1988) Production and use of detritus in various freshwater, estuarine, and coastal marine ecosystems. Limnol Oceanogr 33:910-930

Mann KH (2000) Ecology of coastal waters, with implications for management. Blackwell Science, Oxford

Marsh JA (1976) Energetic role of algae in reef ecosystems. Micronesica 12:13-21

Middelburg JJ, Duarte CM, Gattuso JP (2005) Respiration in coastal benthic communities. In: del Giorgio P, Williams P (eds) Respiration in aquatic ecosystems. Oxford University Press, Oxford

Page HM, Reed DC, Brzezinski MA, Melack JM, Dugan JE (2008) Assessing the importance of land and marine

Editorial responsibility: Otto Kinne,

Oldendorf/Luhe, Germany sources of organic matter to kelp forest food webs. Mar Ecol Prog Ser 360:47-62

Polis GA, Hurd SD (1996) Linking marine and terrestrial food webs: allochthonous input from the ocean supports high secondary productivity on small islands and coastal land communities. Am Nat 147:396-423

Polis GA, Sánchez Piñero F, Stapp P, Rose MD (2004) Trophic flows from water to land: marine input affects food webs of islands and coastal ecosystems worldwide. In: Polis GA, Power ME, Huxel GR (eds) Food webs at the landscape level. University of Chicago Press, Chicago, IL, p 200-216

Reed DC, Foster MS (1984) The effects of canopy shading on algal recruitment and growth in a giant kelp (Macrocystis pyrifera) forest. Ecology 65:937-948

Reed DC, Rassweiler A, Arkema KK (2008) Biomass rather than growth determines variation in net primary production by giant kelp. Ecology 89:2493-2505

Robles C, Robb N (1993) Varied carnivore effects and the prevalence of intertidal algal turfs. J Exp Mar Biol Ecol 166:65-91

Rogers CS, Salesky N (1981) Productivity of Acropora palmata (Lamarck), macroscopic algae, and algal turf from Tague Bay reef, St. Croix, U.S. Virgin Islands. J Exp Mar Biol Ecol 49:179-187

Rosenberg G, Littler DS, Littler MM, Oliveira EC (1995) Primary production and photosynthetic quotients of seaweeds from Sao Paulo state, Brazil. Bot Mar 38:369-377

Russ GR (2003) Grazer biomass correlates more strongly with production than with biomass of algal turfs on a coral reef. Coral Reefs 22:63-67

Sousa WP (1980) The responses of a community to disturbance: the importance of successional age and species' life histories. Oecologia 45:72-78

Sousa WP, Schroeter SC, Gaines SD (1981) Latitudinal variation in intertidal community structure: the influence of grazing and vegetative propagation. Oecologia 48:297-307

Steneck RS, Dethier MN (1994) A functional group approach to the structure of algal-dominated communities. Oikos 69: $476-498$

Taylor RB (1998) Short-term dynamics of a seaweed epifaunal assemblage. J Exp Mar Biol Ecol 227:67-82

Taylor PR, Hay ME (1984) Functional morphology of intertidal seaweeds: adaptive significance of aggregate vs. solitary forms. Mar Ecol Prog Ser 18:295-302

Taylor RB, Rees TAV (1998) Excretory products of mobile epifauna as a nitrogen source for seaweeds. Limnol Oceanogr 43:600-606

Underwood AJ, Kingsford MJ, Andrew NL (1991) Patterns in shallow subtidal marine assemblages along the coast of New South Wales. Aust J Ecol 6:231-249

Vetter EW (1995) Detritus-based patches of high secondary production in the nearshore benthos. Mar Ecol Prog Ser 120:251-262

Vetter EW, Dayton PK (1999) Organic enrichment by macrophyte detritus, and abundance patterns of megafaunal populations in submarine canyons. Mar Ecol Prog Ser 186: $137-148$

> Westphalen G, Cheshire AC (1997) Quantum efficiency and photosynthetic production of a temperate turf algal community. Aust J Bot 45:343-349

Wootton JT (1994) The nature and consequences of indirect effects in ecological communities. Annu Rev Ecol Syst 25:443-466

> Yates KK, Halley RB (2003) Measuring coral reef community metabolism using new benthic chamber technology. Coral Reefs 22:247-255

Submitted: September 1, 2008; Accepted: May 26, 2009

Proofs received from author(s): June 30, 2009 